Prawitri Thalib: Perlindungan Hukum

\title{
PERLINDUNGAN HUKUM TERHADAP PEMEGANG HAK CIPTA DAN PEMILIK LISENSI REKAMAN BERDASARKANUNDANG- UNDANG TENTANG HAK CIPTA
}

\author{
Prawitri Thalib \\ pwi_fansclub@yahoo.com \\ Kantor Wilayah Kementerian Hukum dan Hak Asasi Manusia Provinsi Jambi
}

\begin{abstract}
As for the types of intellectual property rights set forth in the Agreement on Trade Related Aspects of Intellectual Property Rights, Including Tradeon Counterfeit Goods(TRIPs), is Copyright, Patents, Trademarks, Geographical Indications, Integrated Circuit Layout, Secret Trade and Plant Variety Protection. Part of the Intellectual Property Rights that discussed the authors in this paper is Copyright. Copyright is the exclusive right, a right that is recognized by the world, is required to be protected by law but violations of the Copyright are happening everywhere. Proliferation of pirated goods in the form of DVD, VCD, AUDIO CD, CD/DVD Game and Cassette Tape in the market, whereas the Copyright as stipulated in Law No.19 of 2002 on Copyright, Copyright mentioned that the Creatoris the Exclusive Rightsor the Copyright holder to publish or reproduce his workor give permission for it.
\end{abstract}

Keywords: copyrights, exclusive rights, counterfeit.

\begin{abstract}
Abstrak
Adapun mengenai jenis-jenis dari hak kekayaan intelektual yang diatur dalam Agreement on Trade Related Aspects of Intelectual Property Rights, Including Trade on Counterfeit Goods (TRIPs) tersebut adalah Hak Cipta, Hak Paten, Merek, Indikasi Geografis, Tata Letak Sirkuit Terpadu, Rahasia Dagang dan Perlindungan Terhadap Varietas Tanaman. Di mana bagian dari Hak Kekayaan Intelektual yang menjadi pembahasan penulis dalam makalah ini adalah Hak Cipta. Hak Cipta ini adalah hak yang eksklusif, hak yang diakui oleh dunia, diharuskan untuk dilindungi oleh Undang-Undang akan tetapi pelangaran terhadap Hak Cipta tersebut terjadi dimana-mana. Maraknya barang bajakan yang berbentuk DVD, VCD, AUDIO CD, CD/DVD Game dan Tape Cassete yang beredar dipasaran, padahal Hak Cipta ini sebagaimana yang diatur dalam Undang-Undang Nomor 19 Tahun 2002 Tentang Hak Cipta, disebutkan bahwa Hak Cipta adalah Hak Eksklusif Pencipta atau pemegang Hak Cipta untuk mengumumkan atau memperbanyak ciptannya atau memberi izin untuk itu.
\end{abstract}

Kata kunci: hak cipta, hak ekslusif, pembajakan. 


\section{Pendahuluan}

Pada dasarnya kekayaan intelektual (Intellectual Property) ini terbagi dalam dua hal yaitu hak kekayaan industri dan hak cipta. Adapun hak kekayaan industri tersebut terbagi lagi menjadi beberapa hak yang antara lain adalah, Hak Paten (Paten/Paten sederhana), Rahasia Dagang, Merek, Desain Industri, Perlindungan Varietas Tanaman, Desain Tata Letak Sirkuit Terpadu, Indikasi Geografis dan Indikasi Asal serta Kompetisi Terselubung. ${ }^{1}$

Berdasarkan hal uraian diatas tampak bahwa Hak Cipta memiliki kedudukan tersendiri disamping Hak Kekayaan Intelektual lain yang tergabung dalam hak kekayaan industri, atau dapat juga dikatakan bahwa Hak Cipta adalah Hak immaterial, yaitu hak yang tidak dapat dilihat dan diraba tetapi dapat di miliki, ${ }^{2}$ sehingga cukup pantas kalau Hak Cipta ini dikatakan sebagai Hak Eksklusif disamping Hak Kekayaan Intelektual lainnya.

Sementara itu dalam Agreement on Trade Related Aspects of Intelectual Property Rights, Including Trade on Counterfeit Goods (TRIPs),juga mengatur mengenai aspek-aspek yang berhubungan dengan hak kekayaan intelektual, jenis hak kekayaan intelektual, penyelesaian sengketa hak kekayaan intelektual dan pencegahan peredaran perdagangan barang palsu (counterfeit goods).

Oleh karena itu Hak Cipta adalah suatu hak yang harus dilindungi karena, apabila tidak dilindungi akan merugikan orang yang telah bersusah payah berinspirasi, berimajinasi dan berpikir untuk menciptakan sesuatu, oleh karena itu patutlah dikatakan bahwa Hak Cipta merupakan bagian Hak Kekayaan Intelektual yang sangat penting untuk dilindungi, terutama bagi lembaga litbang dan perguruan tinggi yang banyak menghasilkan karya tulis ilmiah, buku, maupun perangkat lunak (software). ${ }^{3}$

Akan tetapi tidak hanya bagi lembaga litbang dan perguruan tinggi saja perlindungan hak cipta juga diperlukan bagi setiap individu pemegang hak cipta agar tidak merasa dirugikan karena karyanya dibajak, sebagai contoh adalah JK Rowling Penulis Inggris yang kaya raya lewat karyanya Harry Potter dengan kekayaan US\$ 1 Miliyar jauh melebihi kekayaan Ratu Inggris sendiri yang hanya US\$397,8 Juta. yang mana hal ini tidak akan pernah ia dapatkan apabila tidak ada perlindungan Hak Cipta atas karyanya tersebut. ${ }^{4}$

Selain untuk melindungi kepentingan lembaga, badan dan individu, perlindungan terhadap hak cipta juga diperlukan bagi suatu negara untuk mendapatkan kepercayaan dari dunia Internasional dan menghindari sanksi internasional. Yang mana kepercayaan dari dunia internasional ini sangatlah diperlukan dalam meningkatkan pertumbuhan ekonomi dalam negeri, karena dengan adanya kepercayaan dari dunia internasional ini diharapkan dapat merangsang

1 Muhammad Ahkam Subroto dan Suprapedi, Pengenalan HKI (Hak Kekayaan Intelektual) Konsep dasar kekayan Intelektual untuk Pertumbuhan Inovasi, Jakarta: PT Indeks, 2008, h.14.

2 Saidin, AspekHukumHakKekayaanIntelektual (Intellectual Property Rights),Jakarta: Rajawali Press, 1995, h. 26.

3 Ibid,h. 36.

4 Ibid,h. 37. 
pertumbuhan pangsa pasar dalam negeri dalam kancah perdagangan internasional.Sekedar untuk diketahui dan dijadikan semacam pelajaran bahwa ada negara yang pernah mendapat sanksi karena pembajakan Hak Kekayaan Intelektual dan negara tersebut adalah Ukraina. Yang mana Amerika Serikat sebagai salah satu negara yang katanya peduli akan masalah Pembajakan Hak Kekayaan Intelektual tersebut pernah menjatuhi Ukraina sanksi ekonomi pada tahun 2003.

Yang mana dalam hal ini Ukraina dianggap sebagai negara yang tidak kooperatif dalam pemberantasan Pembajakan Hak Kekayaan Intelektual, dan lemahnya penegakkan hukum di Ukraina terutaman di bidang perlindungan Hak Kekayaan Intelektual, yang mana hal tersebut ditandai dengan merajarelanya pembajakan Hak Kekayaan Intelektual khususnya adalah Hak Cipta dalam produk optik seperti VCD, DVD, CD Roms termasuk kaset, sehingga Ukraina dijatuhi sanksi perdagangan dan harus membayar denda sebesar US\$ 75 Juta. $^{5}$

Tidak hanya itu Ukraina pun diberikan status "Priority Foreign Countries" sehingga konsekuensi dari status ini Ukraina mengalami pemboikotan oleh negara-negara lain dalam berinvestasi, khususnya para pelaku usaha yang sangat memperhatikan berbagai faktor dalam menanamkan modalnya disuatu negara. ${ }^{6}$

Lain halnya dengan Cina negara ini semenjak bergabung dengan World Trade Organisation (WTO) dapat dikatakan sukses dalam usaha penegakkan hukum Hakkekayaan Intelektual dan dalam usaha pemberantasan pembajakan Hak Kekayaan Intelektual, hal ini ditandai dengan kasus gugatan yang diajukan oleh lima merek terkenal yaitu pemilik merek dagang Chanel (perancis), Prada (Luxemburg), Louis Vuitton (Perancis), Gucci (italia) dan Burberry (Inggris) terhadap pemilik gedung dan pedagang-pedagang pada tahun 2005 silam.

Dimana pengadilan Beijing No 2 Intermediate People's Court tidak hanya menghukum penjual-penjual produk palsu yang ada di Silk Market saja melainkan juga pemilik gedung dinyatakan ikut bertanggung jawab atas penjualan barang palsu tersebut, dengan membayar kerugian kepada pemilik merek sebesar 100.000 Yuan atau sebesar US\$12.319, yang mana hal ini memiliki alasannya karena pemilik gedung mempunyai kewajiban untuk mengawasi dan mencegah peredaran produk-produk palsu, dan dampak positifnya bagi Cina adalah meningkatnya kepercayaan dunia internasional terhadap negara tersebut sehingga hal ini secara tidak langsung juga telah memperluas pangsa pasar dalam negeri maupun luar negeri Cina. ${ }^{7}$

Sedangkan di Indonesia sekalipun dengan berlakunya Asean Free Trade Area (AFTA) dan Agreement on Trade Related Aspects of Intelectual Property Rights, Including Trade on Counterfeit Goods(TRIPs) telah memaksa Indonesia untuk menyelaraskan (ratifikasi) peraturan perundang-undangan di Indonesia di bidang Hak Kekayaan Intrelektual dengan konvensikonvensi Internasional. Masih juga belum dapat memenuhi kewajibannya dalam mencegah pembajakan Hak Kekayaan Intelektual khususnya dalam bidang Hak Cipta, bahkan tindakan

5 Imam Sjahputra,Hak Atas Kekayaan Intelektual (Suatu Pengantar),Jakarta: Harvarindo,2007, h. 79.

6 Ibid,h. 79.

7 Ibid, h. 80. 
pelanggaran ini seolah-olah dapat dikatakan suatu tindakan legal, sebagai contoh apabila kita berkeliling jalan-jalan di Mall ataupun dipasar-pasar tertentu kita mungkin melihat pedagang yang menjual ataupun menyewakan (rental) DVD dan VCD bajakan secaraterang-terangan, padahal ini adalah suatu bentuk pelanggaran Hak Cipta akan tetapi hal ini tampaknya biasabiasa saja bagi kita.

Hal ini bisa saja terjadi di Indonesia dikarenakan sistem penegakan hokum Hak Kekayaan Intelektual Indonesia yang masih seumur jagung apabila dibandingkan dengan AmerikaSerikat yang sudah lebih dari satu abad, selain itu hal ini juga disebabkan oleh manajemen Riset Nasional yang belum jelas, penegakan hukum yang masih lemah dan iklim usaha yang belum kondusif. ${ }^{8}$ Akan tetapi sekalipun di Indonesia masih terdapat beberapa kejahatan pembajakan Hak Cipta, setidaknya pemerintah sudah berusaha untuk menanggulangi kejahatan pembajak tersebut.

\section{Sejarah Perkembangan Hak Cipta di Indonesia}

Mengenai perlindungan terhadap hak cipta ini bermula dari ditemukannya mesin cetak di Inggris pada abad ke 15. sehingga dengan adanya penemuan mesin cetak tersebut penggandaan karya-karya tulis yang kebanyakan adalah buku-buku keagamaan tersebut tidak lagi dilakukan dengan cara ditulis oleh penulis (yang kebanyakan adalah dari kalangan biarawan). Namun dilakukan dengan cara penggandaan melalui mesin yang terbukti menjadi lebih mudah diperbanyak, lebih mudah diproduksi, tidak memakan banyak waktu dan harganya pun jauh menjadi lebih murah dibandingkan diperbanyak secara manual. ${ }^{9}$

Kemudian pada tahun 1445 dengan ditemukannya mesin pencetak yang bergerak (movable type) sebagai pengembangan mesin cetak yang sebelumnya oleh Gutenberg (yang dikenal dunia sebagai penemu mesin cetak), yang selanjutnya dikembangkan pula alat cetak press oleh William Caxton, seni cetak dijalankan secara bebas dan Inggrispun menjadi kota penting untuk pusat percetakan di Eropa pada saat itu.

Namun ketika Raja Henri VIII berkuasa, dia bermaksud untuk mengontrol dan membatasi perdaran buku-buku agama dan politik, sehingga diberlakukan suatu kebijakan baru untuk melarang impor buku-buku ke Inggris. Yang mana kemudian dikeluarkannya suatu UndangUndang pada tahun 1592 yang memberikan hak/sistem keistimewaan (privileges System) kepada perusahaan pencetak buku (stationer company), dimana hanya perusahaan terdaftar saja yang diperkenankan untuk mencetak buku-buku dan hak yang diberikan inilah yang merupakan cikal-bakal berkembangnya hak cipta. ${ }^{10}$

Kemudian dalam perkembangannya sistem ini berlaku cukup efektif hingga pada akhirnya pada tahun 1695 banyak percetakan yang bankrut akibat maraknya pembajakkan

\footnotetext{
8 Muhammad AhkamSubrotodanSuprapedi, Op.Cit, h. 5-6.

9 Imam Sjahputra, Op.Cit., h.113.

$10 \quad$ Ibid, h. 114.
} 
buku. Hingga akhirnya pada tahun 1709 Statue of Anneyang merupakan Undang-Undang Hak Cipta yang pertama kali didunia. Yang mana dalam Undang-Undang tersebut diatur mengenai pembarian jangka waktu perlindungan hukum kepada penulis untuk menerbitkan buku-buku barunya selama 14 tahun, kemudian untuk buku yang dicetak pada tahun 1710 dan diatasnya diberikan proteksi hukum selama 21 tahun, dan perpanjangan selama 14 tahun apabila jangka waktu yang diberikan habis. ${ }^{11}$

Kesadaran mengenai pentingnya pengakuan dan perlindungan dalam bidang hak cipta ini bagi para penulis dan penerbit baru mulai dirasakan oleh masyarakat Eropa pada pertengahan abad ke 19, hingga pada akhirnya lahir Berne Copyright Convention for the Protection of Literary and Artistic Works pada tahun 1886. yaitu konvensi internasional tentang hak cipta yang pertama kali dan yang tertua yang telah direvisi pada tahun 1928 diRoma, 1948 di Brussel dan 1975 di Paris, yang mana inti dari konvensi ini adalah pengakuan dan perlindungan terhadap hak cipta tersebut tidak didasarkan pada kewarganegaraan (nationality) seseorang melainkan dimana karya tersebut diumumkan. Mengenai perlindungan terhadap hak cipta ini terus berkembang hingga disahkannya General Agreement of Tariff and Trade pada tahun 1947 sampai disahkannya pula World Trade Organization pada tahun1994 sebagai ketentuan lebih lanjut mengenai General Agreement of Tariff and Trade tahun 1947 tersebut.

Adapun Berne Copyright Convention for the Protection of LiteraryandArtistic Works baik dulu maupun sekarang dalam perkembangannya tetap memiliki tiga prinsi putama yang antara lain adalah: ${ }^{12}$ 1) Perlakuan Nasional: negara-negara anggota sepakat untuk memberikan perlakuan yang sama terhadap warga negara dari negara-negara anggota Konvensi Paris berdasarkan pada perlindungan hak-hak sebgaimana yang diberikan oleh pemerintah negara anggota kepada warga negaranya masing-masing. (prinsip Most Favoured Nation dalam GATT); 2) Berlaku surut dimana semua ciptaan dilindungi, bahkan ciptaan yang dibuat sebelum perjanjian berlaku kecuali ciptaan yang telah menjadi milik umum (prinsip National Treatmentdalam GATT); 3) Tanpa syarat dimana perlindungan berlaku otomatis dan tidaktergantung pada terpenuhinya persyaratan formal apapun (Prinsip National Treatment dalam GATT).

Adapun dalam rentang waktu 1947 hingga tahun 1994 tersebut ketentuan mengenai perlindungan hak cipta sendiri mengalami perkembangan seiring perkembangan zaman, yang mana hal ini ditandai dengan munculnya berbagai konvensi-konvensi internasional yang berkaitan dengan pengaturan dan perlindungan hak cipta yang antara lain adalah: 1) Universal Copyright Convention 1952; 2) Rome Convention for the Protection of Performers, Producers of Phonograms and Broadcasting Organization 1961; 3) Geneva Conventions for The Protection of Producers of Phonograms Against Unauthorized Duplication of Their Phonograms 1971; 4) Convention Bern 1971; 5) World Intellectual Property Organization Copyrights Treaty

\footnotetext{
11 Ibid, h. 115 .

12 Tamotsu Hozumi, Asian Copyrights Handbook Indonesian Version BukuPanduanHakCipta Asia, Jakarta: Asia/pacific Cultural Centre for UNESCO danIkatanPenerbit Indonesia, 2004, h. 57.
} 
1991.6) World Intellectual Property Organization Performer and Phonogram Treaty1991; 7) Agreement Trade Related Aspects on Intellectual Property Rights(TRIPS) 1994.

Sedangkan di Indonesia sendiri mengenai hak ciptaini sebetulnya sudah diatur sejak zaman penjajahan kolonial Belanda. Yang mana dahulu pada masa penjajahan kolonial Belanda ini hak cipta dikenal dengan istilah hak pengarang dan mengenai hak pengarang ini diatur dalam Staatsblad 1912 Nomor 600, atau yang lebih polupler dengan istilah Auteurswet atau Undang-Undang Hak Cipta.

Oleh karena itu dalam buku-buku terbitan Balai Pustaka sebelum zaman kemerdekaan selalu tercantum hak pengarang dilindungi undang-undang menurut Staatsblad 1912 Nomor 600. Mengenai Staatsbald 1912 Nomor 600 atau Auteurswet 1912 tersebut, pada mulanya diUndangkan di Belanda pada tahun 1912 dan juga diberlakukan di daerah jajahannya di Timur jauh, yaitu Hindia Belanda atau Netherlands Indie dengan beberapa pengecualian, selain itu Auteurswet 1912 ini juga memperbaharui Undang-Undang Hak Cipta sebelumnya yang diundangkan pada tahun 1881, hal ini dikarenakan Blanda hendak manjadi anggota konvensi hak cipta Berne (Berne Copyrights Convention). ${ }^{13}$

Oleh karena Indonesia pada waktu itu menjadi jajahan balanda dengan nama Hindia Belanda, maka jadilah Staatsblad 1912 Nomor 600 tersebut berlaku di Indonesia. Akan tetapi di indonesia sendiri sekalipun pengakuan dan perlindungan terhadap hak cipta ini sudah ada sejak penjajahan kolonial Belanda, kenyataannya pelanggaran terhadap hak cipta pun sudah terjadi sejak zaman penjajahan kolonial Belanda tersebut.

Yang mana salah satu kasus pelanggaran hak cipta yang muncul pada zaman penjajahan kolonial Belanda adalah berbagai buku Eropa yang disadur kedalam bahasa melayu tanpa menyebutkan pengarang aslinya, sebagai contoh adalah buku Si Bachil karya Noer St Iskandar, sebenarnya ini merupakan saduran dari buku L'Avare karya Moliere, namun nama Moliere ini baru dicantumkan pada cetakan yang selanjutnya. Kemudian ada juga karangan Moliere yang lain yang berjudul Le Medicine Malgre Lui yang disadur ke dalam bahasa Sunda oleh Moh Ambri menjadi buku Si Kabayan jadi Dukun, juga diterbitkan tanpa menyebutkan pengarang aslinya. ${ }^{14}$

Mengenai pelanggaran terhadap hak cipta ini seiring dengan kemajuan dan perkembangan zaman serta tehnologi, terutama pada pasca kemerdekaan dan reformasi, objek pelanggaran hak cipta tidak hanya berupa buku, lagu atau lukisan saja namun bisa juga berupa cakram optik atau disc (DVD/VCD) maupun perangkat lunak komputer atau software.

Ini membuktikan seiring munculnya kesadaran akan pentingnya pengakuan dan perlindungan terhadap hak cipta, akan muncul pula tindakan-tindakan pelanggaran hak cipta yang beraneka ragam dan bervariasi. Lalubagaimanadenganprinsip-prinsiphakciptadalamBerne Copyright Convention for the Protection of Literary and Artistic Workstersebut, namun

\footnotetext{
13 Ibid, h. Xv.

14 Ibid, h. xvi.
} 
demikian dengan adanya prinsip-prinsip ini setidaknya meningkatkan kesadaran antar negara supaya dapat saling menghormati hak cipta orang lain supaya bisa saling menguntungkan dan tidak saling merugikan.

Sehingga yang terpenting dari hal tersebut setidaknya telah tumbuh kesadaran akan pentingnya pengakuan maupun perlindungan hak cipta dalam kehidupan berbangsa dan bernegaranya. Dan hal ini ditandai dengan disahkannyaUndang-Undang Republik Indonesia Nomor 6 Tahun 1982 Tentang Hak Cipta yang diubah dengan Undang-Undang Republik Indonesia Nomor 7 tahun 1987 yang kemudian diubah lagi dengan Undang-Undang Republik Indonesia Nomor 12 Tahun 1997, hingga pada pembaharuan terakhirnya adalah UndangUndang Republik Indonesia Nomor 19 Tahun 2002 Tentang Hak Cipta.

Oleh karena itu penyempurnaaan-penyempurnaan kerangka hukum yang berhubungan dengan hak cipta serta tindakan meratifikasi konvensi-konvensi internasional yang berhubungan dengan hak cipta yang dilakukan oleh pemerintah Republik Indonesia, dikarenakan adanya keinginan dari Indonesia selaku anggota WorldTrade Organisation (WTO) untukmemaksimalkan perlindungan hak cipta di Indonesia sebagai hak ekslusif yang harus mendapatkan perlindungan yang ekslusif pula.

Akan tetapi sekalipun improvisasi kerangka hukum dibidang hak cipta mulai mempunyai pengaruh terhadap perlindungan hak cipta di Indonesia, namun dalam penerapannya dilapangan masih jauh dari harapan (Law In Book tidak sesuai dengan Law In Action). Hal ini dikarenakan kerangka hukum yang bertujuan menjamin pengakuan dan perlindungan terhadap hak cipta ini ternyata tidak berjalan dan tidak dilaksanakan sebagaimana mestinya, sesuai dengan maksud yang sesungguhnya dari makna pengakuan dan perlindungan hak cipta itu sendiri.

Selanjutnya yaitu mengenai masalah kerangka hukum pengakuan dan perlindungan hak cipta itu sendiri sehingga diharapkan akan dapat menemukan benang merah dari permasalahan pelanggaran hak cipta ini, yang mana hal ini diharapkan kerangka hukum pengakuan dan perlindungan hak cipta tersebut dapat benar-benar memaksimalkan peranannya dalam melindungi pencipta, pemegang cipta dan hak terkait khususnya serta negara pada umumnya.

\section{Perlindungan HukumTerhadap Hak Cipta Di Indonesia}

Maraknya kejahatan pelanggaran hak cipta tersebut juga tidak terlepas dari kemauan masyarakat untuk mendapatkan barang yang sama dengan harga yang murah, maka mereka pasti akan mencari barang-barang bajakan yang otomatis mempunyai harga jual yang lebih murah apabila dibandingkan dengan produk aslinya.Mengenai produk-produk bajakan tersebut tidak hanya harganya saja yang murah akan tetapi akses mendapatkannya juga mudah, hal ini ditandai dengan banyaknya penjual yang menjual DVD,VCD, Tape Cassete dan CD Game bajakan dipinggir-pinggir jalan maupun dalam Mall-Mall besar, hal ini justru mengakibatkan produsen rekaman ataupun pelaku hak cipta mengalami kerugian baik kerugian materil maupun kerugian immateril, yang secara tidak langsung juga telah merugikan negara karena telah 
mengurangi pemasukkan negara dari penjualan barang-barang yang legal.

Mengenai perbandingan peredaran dari produk legal dan produk bajakan dalam hal rekaman suara yaitu kaset, VCD dan DVD sebelum berlakunya Undang-Undang Nomor 19 tahun 2002 Tentang Hak Cipta (UU No. 19/2002) dapat dilihat pada tabel 2.1 dibawah ini: ${ }^{15}$

Tabel 1. Perbandingan peredaran Produk legal dan produk bajakan karya rekaman suara kaset, VCD dan DVD

\begin{tabular}{cccc}
\hline No & Tahun & Total Unit Produk Legal & Total Unit Produk bajakan \\
\hline 1 & 1996 & 77.552 .008 & 23.068 .225 \\
$\mathbf{2}$ & 1997 & 67.356 .071 & 112.835 .989 \\
$\mathbf{3}$ & 1998 & 41.658 .674 & 137.209 .167 \\
$\mathbf{4}$ & 1999 & 64.464 .951 & 181.505 .780 \\
$\mathbf{5}$ & 2000 & 52.502 .569 & 240.084 .555 \\
$\mathbf{6}$ & 2001 & 44.031 .698 & 290.813 .051 \\
\hline & & 374.565 .971 & 985.516 .767
\end{tabular}

Berdasarkan tabel diatas tersebut tampak bahwa perdaran produk legal tidak tidak mengalami peningkatan yang berati, sedangkan peredaran produk bajakan setiap tahunnya mengalami peningkatan yang signifikan. Tidak hanya itu peredaran produk legal juga tidak sebanding dengan peredaran produk bajakan, yang mana dalam tabel tersebut dapat dilihat bahwa pasca tahun 1996 peredaran produk bajakan melampaui angka seratus juta unit dan bahkan pada awal tahun dua ribu perdaran produk bajakan tersebut melampaui angka dua ratus juta unit hal ini sangatlah mencolok apabila dibandingkan dengan perdaran produk legal yang tidak pernah mencapai angka delapan puluh juta.

Lalu terkait dengan hal diatas juga telah membuat industri rekaman juga mengalami kerugian, yang mana perkiraan kerugian tersebut dapat dilihat pada Tabel 2 dibawah ini: ${ }^{16}$

Tabel 2. Perkiraan kerugian Industri yang diakibatkan Pembajakan karya rekaman suara Kaset, VCD dan DVD

\begin{tabular}{llrrrr}
\hline No & Tahun & \multicolumn{1}{l}{ VCD } & CD & Kaset & \multicolumn{1}{l}{ Total } \\
\hline 1 & 1996 & 0 & 1.295 .770 .000 & 230.312 .030 .000 & 231.607 .800 .000 \\
2 & 1997 & 3.386 .053 .125 .000 & 6.372 .450 .000 & 175.450 .044 .000 & 3.567 .875 .619 .000 \\
3 & 1998 & 4.514 .737 .500 .000 & 38.104 .000 .000 & 111.818 .805 .000 & 1.664 .660 .305 .000 \\
4 & 1999 & 6.879 .600 .000 .000 & 72.765 .490 .000 & 161.049 .187 .000 & 7.113 .414 .677 .000 \\
5 & 2000 & 9.172 .800 .000 .000 & 62.489 .400 .000 & 198.627 .260 .000 & 9.433 .916 .660 .000 \\
6 & 2001 & 11.007 .360 .000 .000 & 95.076 .450 .000 & 271.145 .504 .000 & 11.373 .581 .954 .000 \\
\hline
\end{tabular}

Berdasarkan tabel diatas tampak dengan nyata bahwa jumlah kerugian yang dialami industri akibat dari pembajakan karya rekamansuara bukanlah dalam jumlah yang kecil dan hal tersebut tidak hanya merugikan industri rekaman saja akan tetapi juga secara tidak langsung

15 Abdul RasyidSaliman, et.al, HukumBisnisuntukPerusahaan :TeoridanContohKasus, Jakarta: Kencana, 2007, h. 190.

16 Ibid, h. 190. 
juga telah merugikan negara, yang mana mengenai perkiraan kerugian yan dialami oleh negara akibat tindakan pembajakan tersebut dapat diihat pada Tabel 3 dibawah ini: ${ }^{17}$

Tabel 3. Perkiraan kerugian Negara yang diakibatkan Pembajakan karya rekaman suara Kaset, VCD dan DVD

\begin{tabular}{ccrrrr}
\hline No & Tahun & \multicolumn{1}{c}{ VCD } & \multicolumn{1}{c}{ CD } & \multicolumn{1}{c}{ Kaset } & \multicolumn{1}{c}{ Total } \\
\hline 1 & 1996 & 0 & 46.2777 .500 & 14.394 .501 .875 & 14.440 .779 .375 \\
2 & 1997 & 290.233 .125 .000 & 177.012 .500 & 9.968 .752 .500 & 300.378 .890 .000 \\
3 & 1998 & 386.977 .500 .000 & 952.600 .000 & 4.659 .116 .875 & 392.589 .216 .875 \\
4 & 1999 & 515.970 .000 .000 & 1.299 .383 .750 & 5.297 .670 .625 & 522.567 .054 .375 \\
5 & 2000 & 802.620 .000 .000 & 2.499 .576 .000 & 6.951954 .100 & 812.071 .530 .100 \\
6 & 2001 & 953.625 .600 .000 & 4.617 .999 .000 & 11.059 .882 .400 & 951.303 .481 .400 \\
\hline
\end{tabular}

Oleh karena besarnya jumlah kerugian yang dialami oleh industri maupun yang dialami oleh negara maka terhadap kejahatan hak cipta tersebut tidak boleh dipandang sepele oleh pemerintah, sehingga pemerintah pun sebagai wujud konkrit keinginannya untuk memberantas kejahatan hak cipta tersebut berusaha untuk meningkatkan perlindungan bagi pencipta maupun pemegang hak cipta tersebut.Yang mana salah satu contohnya adalah dengan meningkatkan sanksi pidana dan denda terhadap pelanggaran hak cipta, sebagaimana yang dapat dilihat pada tabel 4 dibawah ini :

Tabel 4.Sanksi Pidana dan Denda Pelanggaran Hak Cipta

\begin{tabular}{cccc}
\hline No & Pelanggaran & Pidana & Denda \\
\hline 1 & Psl 2, 49(1),(2) & 1 bln $<7$ thn & Rp 1 jt $-5 \mathrm{M}$ \\
2 & Psl 2 (1) mengedarkan program & & \\
& komputer & $<5$ thn & Rp 500 jt \\
3 & Psl 17 & $<5$ thn & Rp 1M \\
4 & Psl 19, 20, 49 (3) & $<2$ thn & Rp 150 jt \\
5 & Psl 24, 55 & $<2$ thn & Rp 150 jt \\
6 & Psl 25 & $<2$ thn & Rp 150 jt \\
7 & Psl 27 & $<2$ thn & Rp 150 jt \\
8 & Psl 28 & $<5$ thn & Rp 500 jt \\
\hline
\end{tabular}

Berdasarkan tabel tersebut tampak bahwa sanksi terhadap pelanggaran hak cipta sangatlah berat akan tetapi kejahatan terhadap hak cipta juga terus terjadi (seperti maraknya penjualan VCD,DVD, Kaset atau CD Game bajakan) dipasaran, hal tersebut dapat terjadi dikarenakan kurangnya kinerja aparat atau masih lemahnya instrumen hukum yang mengatur hak cipta tersebut.

Sebagai faktanya dapat dilihat dari penjelasan berikut: 1) Bahwa hak cipta dilihat dari fungsi dan sifatnya adalah hak pribadi, yang mana dengan kata lain kejahatan hak pribadi tersebut adalah delik aduan, bukan delik biasa; 2) Dalam Pasal 56UU No. 19/2002 tersebut,disebutkan bahwa kejahatan hak cipta merupakan delik aduan dan pasal inilah yang membuka peluang

17 Ibid, h. 191. 
bagi pemegang hak cipta atau penerima hak cipta untuk mengajukan tuntutan terhadap apra pelaku kejahatan hak cipta.

Oleh karena antara sifat pribadi (privat) dari hak yang ingin dilindungi, ditambah lagi dengan ketentuan dari Pasal 56 UU No. 19/2002 yang mempertegas bahwa kejahatan terhadap hak cipta adalah delik aduan, maka hal inilah yang menghambat perlindungan maksimal terhadap hak cipta karena kejahatan hak cipta dianggap sah apabila tidak ada pengaduan dari pihak yang dirugikan serta aparat hukum pun tidak bisa menindak pelaku kejahatan hak cipta apabila tidak ada yang mengadu merasa dirugikan oleh kejahatan hak cipta tersebut dan hal ini pula yang menjadi peluang bagi para oknum untuk terus melakukan kejahatan di bidang hak cipta.

\section{Kesimpulan}

Bahwa perkembangan mengenai hak cipta ini terus berkembang seiring perkembangan zaman, mulai dari ditemukannya mesin cetak hingga ditemukannya program komputer dan cakram optik dan bentuk kejahatannya pun terus berkembang mulai dari pembajakan buku hingga penggandaan program komputer sampai penggandaan cakram optik.Bahwa terdapat pertentangan antara fungsi dan sifat dari hak cipta dengan kerangka hukum yang melindungi hak cipta tersebut. Kerangka hukum mengenai perlindungan hak cipta ini hendaknya terus disesuaikan dengan perkembangan zaman, supaya bentuk kejahatan dibidang hak cipta ini tidak begitu mudah berkembang seiring perkembangan zaman.harus segera ditetapkan secara tegas mengenai delik dari hak cipta ini apakah ini delik aduan mengikuti fungsi dan sifat dari hak cipta tersebut, ataukah delik biasa mengesampingkan fungsi dan sifat dari hak cipta tersebut sebagai hak pribadi.

\section{Daftar Bacaan}

Fuady, Munir, Pengantar Mukum Bisnis Menata Bisnis Modern di Era Global, Cetakan Pertama, Bandung: Citra Aditya Bakti, 2002.

Saidin,AspekHukumHakKekayaanIntelektual (Intellectual Property Rights),Jakarta: Rajawali Press, 2004.

Saliman, Abdul Rasyid et al., Hukum Bisnis untuk Perusahaan : Teori dan Contoh kasus, Cetakan Ketiga, Jakarta: Kencana, 2007.

Sjahputra, Imam, Hak Atas Kekayaan Intelektual (Suatu Pengantar), Harvarindo, 2007.

Subroto, Muhammad Ahkam dan Suprapedi,Pengenalan HKI (Hak Kekayaan Intelektual) Konsep dasar kekayan Intelektual untuk Pertumbuhan Inovasi, Jakarta: Indeks, 2008.

Tamotsu Hozumi; Asian Copyrights Handbook Indonesian Version BukuPanduanHakCipta Asia, Jakarta: Asia/pacific Cultural Centre for UNESCO danIkatanPenerbit Indonesia, 